
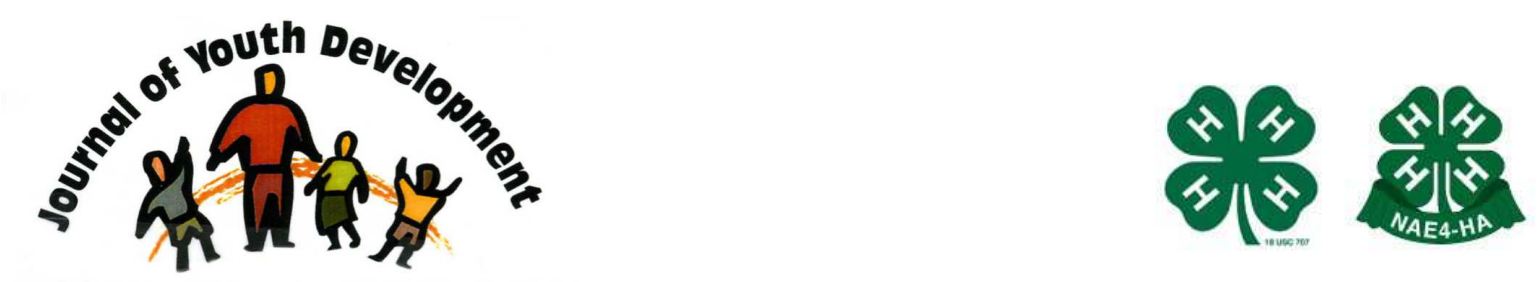

Bridging Research \& Practice

\title{
Qualitative and Quantitative Assessments of Thriving and Contribution in Early Adolescence: Findings from the 4-H Study of Positive Youth Development
}

\author{
Amy Eva Alberts \\ Tufts University \\ Lincoln Filene Building, Rm 312 \\ Medford, MA 02155 \\ Phone: 617-627-4509 \\ Fax: 617-627-5596 \\ amy.alberts@tufts.edu \\ Elise DiDenti Christiansen \\ Boston College \\ elisedidenti@hotmail.com \\ Paul Chase \\ Tufts University \\ paul.chase@tufts.edu \\ Sophie Naudeau \\ Tufts University \\ sophienaudeau@hotmail.com \\ Erin Phelps \\ Tufts University \\ erin.phelps@tufts.edu \\ Richard M. Lerner \\ Tufts University \\ richard.lerner@tufts.edu
}




\title{
JOURNAL OF YOUTH DEVELOPMENT \\ bridging research and practice

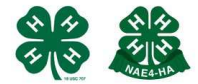

Bridging Research \& Practice

Volume 1, Number 2, September 2006

Article 0602FA002

\section{Qualitative and Quantitative Assessments of Thriving and Contribution in Early Adolescence: Findings from the 4-H Study of Positive Youth Development}

Amy Eva Alberts, Paul Chase, Sophie Naudeau, Erin Phelps and Richard M. Lerner Tufts University

Elise DiDenti Christiansen

Boston College

\begin{abstract}
Research and practice in youth development converge in an interest in positive development, or thriving. They converge also in seeking to promote among youth an orientation to act in support of their own and others' well-being through contributions to self, family, and community. Based on the results of both qualitative (open and axial coding of parents' and students' answers to several open-ended questions) and quantitative analyses of data from Wave 2 (Sixth Grade; 2003-2004) of the 4-H Study of Positive Youth Development (PYD), we found that adolescents and parents define a thriving youth in different ways and, as well, that the groups differ in the salience of contribution as part of their respective conceptions of thriving. We discuss the implications for research and practice of the two generational groups' contrasting views of thriving and contribution.
\end{abstract}

\section{Background}

Current emphases in both research and practice pertinent to youth development suggest that all adolescents have strengths and when these strengths are aligned with the resources (or "assets") for healthy development present within their communities, positive development will be promoted (Lerner, 2004; Lerner, et al., 2005). During the adolescent years, exemplary development has been hypothesized as being constituted by psychological, behavioral, and social characteristics reflecting "Five Cs," that is, competence, confidence, caring, character, and positive social connections (e.g., Eccles \& Gootman, 2002). When these "Five Cs" develop in a young person, he or she may be seen as thriving. In turn, among thriving youth a Sixth C, contribution (to self, family, community, and civil society), is believed to develop (Lerner, 2004). 
Some youth development organizations, such as 4-H and Boys \& Girls Clubs, have emphasized that their programs help lead a thriving young person toward contribution (e.g., see Roth \& Brooks-Gunn, 2003a, 2003b). However, it was not until the launching of the 4-H Study of Positive Youth Development (PYD) that empirical evidence was presented for the presence of the Five Cs (as first-order latent constructs), for their convergence on a second-order latent construct of PYD, and for the presence as well of the sixth C of contribution (Lerner, et al., 2005).

The 4-H Study of Positive Youth Development, funded by the National 4-H Council, is concerned with the identification of the individual and contextual factors that lead to PYD, and ultimately, youth contributions to self, others, and community. The study is predicated on developmental systems theories that stress the potential for plasticity in development across the life span. In this conception, plasticity arises through individual $\leftrightarrow$ context relations. Such contributions are envisioned to involve both a behavioral (action) component and an ideological component (that is, the young person's acts of contribution are predicated on a commitment to moral and civic duty) (Lerner, Dowling, \& Anderson, 2003). Youth who believe they should contribute to self and context and who act on these beliefs reflect and promote their own positive development, as well as the "health" of their social context. This is theoretically referred to as adaptive person $\leftrightarrow \rightarrow$ context developmental regulations.

While theory and preliminary data suggest the importance of youth contribution, we know less about the extent to which youth and parents value contribution as a central component of positive development (or thriving). Certainly, if young people and their parents do not regard contribution as an important outcome of participation in youth development programs and/or as a central component of a thriving youth, then theories linking PYD and contribution would be deficient in their ecological validity. In addition, practitioners placing emphasis on the development of contribution as a key "deliverable" of their programs would not fit well with the interests of their clientele if the enhancement of contribution was not of core interest to youth and parents.

Of course, parents and youth can and do respond to quantitative questions about the significance or salience of indicators of contribution (e.g., Benson, Leffert, Scales, \& Blyth, 1998; Lerner, et al., 2005; Scales, et al., 2000). Nevertheless, such quantitative data do not necessarily reflect the unprompted salience of constructs relevant to contribution in the conceptions held by adolescents and their parents regarding the meaning of a thriving young person. Accordingly, qualitative data are useful for allowing assessment of the unprompted salience of contribution and, through triangulation with quantitative data, assessing the ecological validity of emphases in both theory and practice on the importance of contribution in defining and acting to promote positive youth development, respectively.

Accordingly, in the present study we sought to:

- First, use qualitative information available in the 4-H Study of PYD data set to assess the unprompted salience of constructs related to contribution and to the "Five Cs" of PYD in the conceptions of adolescents and parents about the nature of a thriving young person.

- $\quad$ Second, because past research has revealed that indicators of PYD vary in regard to sex and socioeconomic status (SES) (e.g., Fredricks \& Eccles, in press; Lerner, et al., 2005), we also assessed the covariation between participants' sex and SES, and youth 
identification of contribution to self, family, and community when describing a thriving youth.

- Third, the research assessed whether the evidence about youth contribution and PYD garnered through qualitative analyses could be triangulated with quantitative data about these constructs.

\section{METHODS}

The current investigation was conducted as a part of the 4-H Study of Positive Youth Development (PYD), which is a longitudinal investigation starting with $5^{\text {th }}$ grade youth in the United States and their parents. The 4-H study is designed to test a theoretical model about the role of developmental assets in the promotion of PYD, as conceptualized by the "Five Cs" of

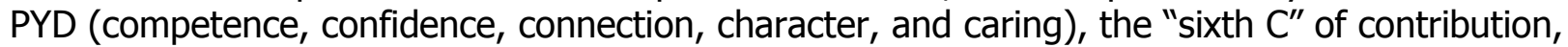
and the corresponding diminution of problem and risk behaviors (Lerner, et al., 2005). Full details of the methodology of the 4-H Study have been presented in prior reports (Lerner, et al., 2005; Theokas \& Lerner, in press; also see Jelicic, et al., 2006). Accordingly, we present those features of methodology pertinent to the focus of this investigation.

\section{Design}

The 4-H Study uses a form of longitudinal sequential design (Baltes, Reese, \& Nesselroade, 1977). Fifth graders, gathered during the 2002-2003 school year (Wave 1 of the study), were the initial cohort within this design. To maintain at least initial levels of power for within-time analyses and to assess the effects of retesting, all subsequent waves of the study involve the addition of a "retest control" cohort of youth who are in the current grade level of the initial cohort; this new cohort is then followed longitudinally.

Accordingly, in Wave 2 of the study (sixth grade for the initial cohort), a retest control group of sixth graders who were new to the study were gathered; these youth became members of a second longitudinal cohort. Similarly, each subsequent wave of the study introduces a new cohort which is then followed longitudinally throughout the rest of the study.

The present report provides data from the second wave of the 4-H Study and, as such, presents the results of analyses involving two different subsets of the overall set of study participants. That is, the present sample of sixth graders includes participants from the initial cohort who remained in the longitudinal sample for Wave 2 and the new cohort of sixth graders, who were introduced into the study as members of the Wave 2 retest control group. Details about these groups of participants are provided below.

\section{Participants}

The Wave 2 sample was comprised of 982 sixth grade youth from the initial Wave 1 cohort ( $45.6 \%$ males; $54.4 \%$ females) and, as well, a "retest control" sample of 893 sixth graders (39.3\% males; $60.7 \%$ females). The combination of longitudinally studied (Wave 1-Wave 2) participants from the initial cohort and the retest control participants from Wave 2 resulted in a total of 1,875 sixth grade participants at Wave $2(42.6 \%$ males; mean age $=12.18$ years, $S D=$ .87 years; $57.4 \%$ females; mean age $=12.09$ years, $\mathrm{SD}=.80$ years). Wave 2 participants came from sites located in 18 states across the nation. Participants varied in regard to race/ethnicity, socioeconomic status, family structure, rural/urban location, geographic region, and experiences in after-school programs (Lerner, et al., 2005). Schools were chosen as the main method for collecting the sample. 
For the present report we focused on a subsample $(N=691)$ of the overall Wave 2 participants. That is, given our interest in comparing youth and parent conceptions of thriving, the subsample of adolescent participants we used consisted of all adolescent responses for whom we had matching parent responses.

The Student Questionnaire (SQ) and the Parent Questionnaire (PQ)

As mentioned above, the measurement model used in the larger 4-H Study of PYD was designed to provide indices that would test the developmental contextual, individual $\leftrightarrow \rightarrow$ context model of the development of PYD. Accordingly, the SQ included measures pertinent to the "Five Cs" of PYD, problem behaviors, pubertal level of development, individual and ecological assets, developmental regulation, activities, and demographics. The PQ was composed of two types of items: (a) items about the parent or guardian and (b) items about the child. Information regarding the specific items included in both questionnaires can be found in Lerner, et al. (2005).

In regard to the present research, youth and their parents responded to open-ended questions intended to appraise self-generated definitions of thriving in adolescence. In addition, youth provided data on several quantitative measures of contribution and PYD, which were used for the purpose of triangulation with qualitative data on these constructs. The SQ and PQ qualitative questions are presented below (see "Coding of qualitative data"). Information about the quantitative measurement of youth contribution and PYD is presented in Lerner, et al. (2005).

\section{Procedure}

For Wave 2 of data collection (2003-2004), teachers or program staff gave children an envelope to take home to their parents, which contained a letter explaining the study, consent forms, a parent questionnaire, and a self-addressed envelope for returning the parent questionnaire. Data collection was conducted by project staff or by assistants hired for testing at remote locations. Students, who were unable to be surveyed at their school or 4-H site because they were either absent during the day of testing, or because the school superintendent did not allow Wave 2 testing to occur in the school, received a survey in the mail. Parents were asked to complete the Parent Questionnaire (PQ) at home and to return it via mail.

\section{Coding of qualitative data}

The foci of the present research were pursued through analyses of qualitative and quantitative data available within the 4-H Study data set. Across both youth and parents, the construction of the qualitative data base required the development and implementation of a system of coding several open-ended questions.

Youth responded to four open-ended questions:

1. Everybody knows kids in their school or neighborhood that they think are doing well in all areas of their life. In your opinion, what is he or she like? What sort of things does he or she do?

2. Everybody also has an idea about how she or he would like to be. If you imagine yourself doing really well in all areas of your life, what would you be like? What sorts of things would you do?

3. Now, think about yourself and your life now. How would you describe how you are doing? What are you like? What sorts of things do you do?

4. What do you think is the most important/meaningful thing that you do? 
Youth answers were coded by two raters through a combination of open coding (i.e., identification of concepts within the data) and axial coding (i.e., relating categories to their subcategories) (Strauss \& Corbin, 1998). While raters did create codes for data not captured by a preconceived theoretical framework, coding predominantly reflected the general concepts used in the PYD literature (i.e., the five Cs of competence, confidence, connection, character, caring, and the sixth $\mathrm{C}$, contribution). This decision was based on recent work by King, et al. (2005), who found that definitions of thriving by adults and youth were able to be organized according to the "five Cs" of PYD. A preliminary codebook was developed by two raters based on the answers provided by 75 randomly selected participants.

To ascertain coding reliability across the raters, each rater used this preliminary codebook to independently code an additional 75 randomly selected cases. There was a $91.26 \%$ agreement between the two raters and a high Cohen's kappa, $k=.92$. Given this consistency, the remaining youth answers were coded by one of the two raters.

Parents responded to the following qualitative questions: How can you tell if an adolescent is thriving or doing really well in all areas of their lives? In your opinion, what is he or she like, what sorts of things does he or she do? Unlike the youth participants, parents were only asked one question intended to capture their definitions of thriving. This decision was based on adults' general level of comprehension and relative capacity to provide succinct answers, as well as the need to keep the Parent Questionnaire relatively short.

Parents' answers were also coded by two raters through a combination of open and axial coding. Once again, the two raters created codes reflective of concepts used in the PYD literature and, as well, codes were developed for data not captured by this preconceived theoretical framework. The two raters developed a preliminary codebook based on the answers provided by 100 randomly selected participants. Inter-rater reliability was determined for a random sample of 100 cases. There was an $86.83 \%$ agreement between the two raters and a high Cohen's kappa, $k=.88$. Given this consistency, the remaining parent answers were coded by one of the two raters.

The goals of this study included:

\section{RESULTS}

- To assess through using qualitative data from the 4-H Study the unprompted salience of constructs related to contribution and to the "Five Cs" of PYD in the conceptions of adolescents and parents about the nature of a thriving young person

- To assess the association between participants' sex and SES and the likelihood of whether adolescents mentioned contribution to self, family, and community when describing a thriving youth

- To assess whether qualitative data could be triangulated with quantitative data about youth contribution to community and PYD.

Accordingly, the first analyses of the open-ended questions asked of parents and youth were conducted to determine whether parents and youth define thriving in similar or different ways and, specifically, whether contribution was a salient component of either group's conceptions of a thriving youth. 
Is contribution part of adolescents' or parents' conceptions of a thriving youth?

Throughout this study we examined two questions: First, "What is the prevalence of youth and parents who mention contribution to self, family, and community as a part of thriving or/and as an important thing that youth do?" Second, "Do parents and students define thriving in similar or different ways?"

Table 1 presents the percentages of parents/guardians and youth who mentioned the " 5 Cs," Contribution, and other attributes of youth development in answering the open-ended questions included at Wave 2. Parent/guardian and youth proportions that significantly differ are in bold in Table 1. Table 2 presents a selection of parent and youth quotations illustrating codes associated with the "Five Cs" of PYD and other attributes of youth development. 
Table 1

Proportion of Parents or Guardians and Youth who Mentioned the "Five Cs" of PYD, Contribution, and Other Attributes of Youth Development in their Definitions of Thriving

\begin{tabular}{|c|c|c|c|}
\hline \multirow{2}{*}{\multicolumn{2}{|c|}{ Codes }} & \multicolumn{2}{|c|}{$\begin{array}{l}\text { Proportion of sample to mention code at least } \\
\text { once }\end{array}$} \\
\hline & & Parents or Guardians & Youth \\
\hline \multicolumn{4}{|c|}{ The "5 Cs" of PYD and Contribution } \\
\hline & Competence (all sub-codes) & 34.9 & 62.5* \\
\hline & Competence: academic & 19.3 & 47.0 \\
\hline & Competence: other (e.g., social) & 22.8 & 34.6 \\
\hline & Confidence & 7.2 & 3.8* \\
\hline & Connection & 25.4 & 36.2* \\
\hline & Character & 14.1 & 48.8* \\
\hline & Caring & 6.0 & 21.9* \\
\hline & PYD (computed as the sum of Cs) & 52.0 & 86.4 \\
\hline & One C & 24.7 & 26.1 \\
\hline & Two Cs & 20.1 & 34.4 \\
\hline & Three Cs & 6.2 & 22.6 \\
\hline & Four Cs & 0.9 & 3.2 \\
\hline & Five Cs & 0.1 & 0.0 \\
\hline & Contribution (all sub-codes) & 13.6 & 42.0* \\
\hline & Contribution to self & 7.3 & 6.1 \\
\hline & Contribution to family & 2.6 & 14.0 \\
\hline & Contribution to community & 5.0 & 28.9 \\
\hline \multicolumn{4}{|c|}{ Participation in activities } \\
\hline & Sports & 18.5 & 52.0 \\
\hline & Arts and crafts & 2.6 & 4.9 \\
\hline & Dance/music/singing/drama & 6.7 & 13.0 \\
\hline & Many different activities & 5.2 & 3.9 \\
\hline & Movies/TV & 2.0 & 4.3 \\
\hline & Outdoors & 3.9 & 4.2 \\
\hline & Play/have fun (includes "hanging out") & 7.5 & 25.2 \\
\hline & Reading/writing & 4.2 & 7.7 \\
\hline & Youth development & 1.1 & 2.5 \\
\hline & Go to school/learn & 0.0 & 13.0 \\
\hline \multicolumn{4}{|c|}{ Other youth attributes } \\
\hline & Absence of negative behaviors & 0.7 & 3.9 \\
\hline & Professional/educational aspirations & 1.4 & 21.7* \\
\hline & Active & 5.2 & 3.3 \\
\hline & Bright/smart & 1.0 & 21.3* \\
\hline & Communicative/open & 13.6 & 0.7 \\
\hline & Curious about new things & 4.5 & 0.4 \\
\hline & Sense of humor & 2.9 & 10.9 \\
\hline & Positive attitude/orientation to life & 7.0 & 3.8 \\
\hline & Happy & 23.6 & 3.9* \\
\hline & Positive orientation to school & 3.6 & 2.3 \\
\hline & Religiosity/spirituality & 4.4 & 7.5 \\
\hline
\end{tabular}

$*$ These parent/guardian and youth proportions are significantly different. All $\underline{z}$ scores exceed 2.58 and all $p s$ are $<.01$. 


\section{Table 2}

A Selection of Parent or Guardian and Youth Quotations that Illustrate Codes Associated with the "Five Cs" of PYD and Other Attributes of Youth Development

\begin{tabular}{|c|c|c|}
\hline \multirow[b]{2}{*}{ Codes } & \multicolumn{2}{|c|}{ Responses } \\
\hline & Parent or Guardian & Youth \\
\hline Competence & $\begin{array}{l}\text { "Like to balance both his academic } \\
\text { and physical activities so that he } \\
\text { doesn't burn out at a young age." }\end{array}$ & $\begin{array}{l}\text { "I would be able to handle and do } \\
\text { everything really well." }\end{array}$ \\
\hline $\begin{array}{l}\text { Competence: } \\
\text { academic }\end{array}$ & $\begin{array}{l}\text { "Involved and successful } \\
\text { academically, socially, and } \\
\text { physically in school." }\end{array}$ & $\begin{array}{l}\text { "I'd study hard and get good } \\
\text { grades and try to get into college." }\end{array}$ \\
\hline $\begin{array}{l}\text { Competence: } \\
\text { other (e.g., social) }\end{array}$ & $\begin{array}{l}\text { "They are well-liked and move } \\
\text { easily in circles of friends." }\end{array}$ & $\begin{array}{l}\text { "I would try to talk to everyone } \\
\text { and be very friendly with } \\
\text { everyone." }\end{array}$ \\
\hline Confidence & $\begin{array}{l}\text { "An adolescent is happiest when } \\
\text { they are comfortable with } \\
\text { themselves." }\end{array}$ & "I would be proud of myself." \\
\hline Connection & $\begin{array}{l}\text { "Parents are involved with their } \\
\text { activities." }\end{array}$ & $\begin{array}{l}\text { "Have a great relationship with } \\
\text { family." }\end{array}$ \\
\hline Character & $\begin{array}{l}\text { "Respectful and courteous to those } \\
\text { he interacts with including friends, } \\
\text { teachers, and family." }\end{array}$ & $\begin{array}{l}\text { "I would try to be the best person I I } \\
\text { could be, like being nice to people." }\end{array}$ \\
\hline Caring & $\begin{array}{l}\text { "Is interested in the feelings and } \\
\text { the well being of others." }\end{array}$ & $\begin{array}{l}\text { "Really caring for others and have } \\
\text { a good heart." }\end{array}$ \\
\hline Contribution to self & $\begin{array}{l}\text { "He eats well and enough rest and } \\
\text { physical activity." }\end{array}$ & $\begin{array}{l}\text { "I would be very active and } \\
\text { healthy." }\end{array}$ \\
\hline Contribution to family & "Helps out with chores at home." & $\begin{array}{l}\text { "I would be like a mother. I would } \\
\text { take care of my sisters and } \\
\text { brothers." }\end{array}$ \\
\hline $\begin{array}{l}\text { Contribution to } \\
\text { community }\end{array}$ & $\begin{array}{l}\text { "Serves or gives back to } \\
\text { community." }\end{array}$ & $\begin{array}{l}\text { "I would help the homeless and } \\
\text { endangered species. And I would } \\
\text { help make peace on earth!" }\end{array}$ \\
\hline $\begin{array}{l}\text { Professional/educational } \\
\text { aspirations }\end{array}$ & $\begin{array}{l}\text { "He is determined to get his } \\
\text { education, so that when he grows } \\
\text { up, he will be successful." }\end{array}$ & $\begin{array}{l}\text { "Going to a good school and } \\
\text { getting a good education." }\end{array}$ \\
\hline Bright/smart & $\begin{array}{l}\text { "Has a good head on her } \\
\text { shoulders." }\end{array}$ & $\begin{array}{l}\text { "I think she is good in everything } \\
\text { so she is smart, and intelligent." }\end{array}$ \\
\hline Happy & $\begin{array}{l}\text { "They are generally happy and } \\
\text { satisfied with themselves and the } \\
\text { world around them." }\end{array}$ & $\begin{array}{l}\text { "At school or at home just be } \\
\text { happy." }\end{array}$ \\
\hline
\end{tabular}

The data in these tables show that parents and youth indeed differ in what they emphasize when describing a thriving youth. Within both, the parent group and the youth group, if a term pertinent to a $\mathrm{C}$ was mentioned it was most commonly linked to competence. However, a greater proportion of youth included the "Cs" of competence, connection, character, and caring in their definitions of thriving than did their parents. Youth were also more likely to mention professional/educational aspirations (21.7\%) and the personal characteristic of being bright/smart ( $21.3 \%)$ than were their parents $(1.4 \% \& 1.0 \%$, respectively). In turn, although less frequent than youth in their use of terms that fit overall with the Five Cs, parents thought a 
thriving young person was someone who was happy $(23.6 \%)$; their mention of this attribute exceeded the frequency with which youth used this term (i.e., 3.9\%).

However, of particular importance for the present research, the data in Table 1 indicate that there was a substantial disparity in the proportion of parents $(13.6 \%)$ and youth $(42 \%)$ who mentioned the "Sixth C" of contribution. As measured within the present research, it appears then that contribution is seen by youth as a much more salient attribute of a thriving young person than is the case among parents. In addition, when parents did mention contribution as a facet of a thriving youth they were more likely to emphasize contribution to self $(7.3 \%)$, while youth focused most on contribution to community $(28.9 \%)(p<.01)$.

These findings suggest that the emphasis among researchers and practitioners on promoting youth contribution corresponds more with views of what characterizes a thriving youth held by young people themselves than by their parents. It is important to ask, however, given that past PYD research has demonstrated sex and socioeconomic status (SES) effects for youth contribution (Fredricks \& Eccles, in press; Lerner, et al., 2005), if these youth-parent differences vary also in relation to the sex of the young person or his or her SES.

In regard to sex, boys and girls did not significantly differ in their views about contributions to self. However, the proportion of girls who mentioned contribution to family at least once was significantly higher than was the proportion of boys, $X^{2}(1)=6.06, p \leq .014$. Similarly, the proportion of girls who mentioned contribution to community at least once was significantly higher than was the corresponding proportion of boys, $X^{2}(1)=9.98, p \leq .002$.

SES was measured through parental report of household income and was dichotomized (i.e., median-split: below the median $[\$ 45,000]$ and above the median). Youth with low SES were significantly more likely than youth with high SES to mention contribution to family at least once, $X^{2}(1)=14.39, p \leq .000$. No significant differences were found between the two groups in regard to contribution to self and contribution to community.

In short, then, contribution, when measured through qualitative analyses, appears to be a generally more salient feature of thriving in the views of youth, and perhaps - in regard to some facets of contribution - especially for girls and in lower SES groups, than is the case for parents. Do these findings from qualitative analyses converge with analyses of quantitative data? The answer appears to be yes.

\section{Do qualitative data triangulate with quantitative data about youth contribution to community and PYD?}

Establishing the convergence between qualitative and quantitative assessments of contribution is important for validating one's findings and, as well, for deriving recommendations for practice. Data pertinent to contribution can only be addressed within the youth sample, since quantitative measures of contribution to community and PYD were not included within the Parent Questionnaire.

Youth scores on the quantitative measure of contribution to community were significantly correlated with youth mentioning contribution to community as a part of their responses to the open-ended questions, $r(603)=.095, p=.02$. That is, the two measures (i.e., qualitative and quantitative) of contribution to community significantly covary. 
Analyses also revealed significant, albeit small, relationships between quantitative and qualitative indices of PYD.

Youth scores on the quantitative measure of PYD were significantly correlated with youth including the "Five Cs" of PYD in their definitions of thriving, $r(662)=.264, p<.01$. This covariation of qualitative and quantitative measures of PYD was significant for both males and females, $r(266)=.219, p<.01$ and $r(396)=.252, p<.01$, respectively. The PYD measures were also significantly correlated for both high and low SES youth, $r(355)=.300, p<.01$ and $r(235)=.133, p<.05$, respectively.

\section{Discussion}

Theories of positive youth development (PYD) and practitioners' efforts to promote such development converge in emphasizing that the outcome of a young person's growth through adolescence, especially when that young person is involved in programs aimed at fostering PYD (Lerner, 2004; Roth \& Brooks-Gunn, 2003a, 2003b), should be contributions to self, family, community and - ultimately - civil society. If both, theory and the goals of practice are to find support, then it would be beneficial if the people who participate in youth development programs - both parents and their children - agreed that a key outcome of participation in youth development programs are such multifaceted youth contributions. They would then agree that a thriving young person should manifest not only the "Five Cs" of PYD but, as well, the attribute of contribution (to self and context) (Lerner, 2004).

The results of the present research indicate, however, that parents - as key clientele of youth development programs - do not share in what seems to be a convergence among researchers, practitioners, and youth themselves in perceiving a thriving young person as either possessing attributes associated with the "Five Cs" or as making multi-faceted contributions to self and context. Through the use of qualitative information within the 4-H Study of PYD (Lerner, et al., 2005; Theokas, et al., 2005), we were able to assess the unprompted salience of constructs related to contribution and to the "Five Cs" of PYD in the conceptions of adolescents and parents about the nature of a thriving young person. We found that youth included characteristics associated with the Cs in their definitions of thriving more often than did their parents. Parents placed an emphasis on the thriving young person as happy and, as well (and consistent with at least one $\mathrm{C}$ ), competent. Moreover, youth were much more likely to emphasize contribution in their conceptions of a thriving young person than were parents. When parents did mention terms associated with contribution, they were more likely to focus on contributions to self (e.g., staying happy, keeping healthy) than contributions to the context (i.e., family or community). Although our findings suggested that some variation exists across sex and SES, this variation does not contradict these overall generational differences.

Moreover, since the qualitative findings about contribution from the present research converge with the quantitative data about contribution available for youth within the 4-H Study data set, we believe there is evidence for the validity of our findings and thus for the assertion that there are some important implications of our results for both theory and practice.

Researchers believe that to promote both the "Five Cs," as key indicators of PYD, and contribution, as a key "outcome" of the development of these attributes of a thriving youth, there needs to be consistent support across the breadth of the social ecology of youth (Theokas \& Lerner, In press). In particular, developmental assets represented by other people - for instance, parents, teachers, and leaders of youth-serving programs - should converge in 
building a collaborative community for youth (Benson, Scales, Hamilton, \& Sesma, 2006;

Theokas \& Lerner, in press). In turn, practitioners working within youth-serving programs want to be in accord with the values of the parents of the youth they are serving.

Accordingly, given the results of the present research, practitioners may need to work to better align their conceptualization of a thriving youth with those of the parents they are serving. While both groups want "good things" for youth, there are differences in how "good" is understood and, in settings where resources of time and money are limited, these different ideas may result in disagreements about priorities. In turn, researchers should investigate how the sources of theory, practice, and the views of youth converge, why there is divergence with the views of parents, and whether and how enhancing alignment among all groups can serve to benefit the overall healthy development of youth.

The present findings pertain only to the early portion of the adolescent period. If the present findings are replicated and, as well, extended to subsequent portions of adolescence, then there is an important agenda for collaboration among researchers, practitioners, parents, and young people. Together, we must build a more collaborative community for promoting positive development among the diverse young people of our nation.

\section{References}

Baltes, P. B., Reese, H. W., \& Nesselroade, J. R. (1977). Life-span developmental psychology: Introduction to research methods. Brooks/Cole, Oxford: England.

Benson, P. L., Leffert, N., Scales, P. C., \& Blyth, D. A. (1998). Beyond the "village" rhetoric: Creating healthy communities for children and adolescents. Applied Developmental Science, 2(3), 138-159.

Benson, P. L., Scales, P. C., Hamilton, S. F., \& Sesma, A., Jr. (2006). Positive youth development: Theory, research and applications. In R. M. Lerner (Ed.), Theoretical models of human development. Volume 1 of Handbook of Child Psychology (6th ed.). Editors-in-chief: W. Damon \& R. M. Lerner. Hoboken, NJ: Wiley.

Eccles, J., \& Gootman, J. A. (2002). Community programs to promote youth development. Washington, D.C.: National Academy Press.

Fredricks, J. \& Eccles, J. (In press). Is extracurricular participation associated with beneficial outcomes? Concurrent and longitudinal relations. Developmental Psychology.

Jelicic, H., Bobek, D. L., Phelps, E., Lerner, R. M., \& Lerner, J. V. (In preparation). Using positive youth development (PYD) to predict positive and negative outcomes in adolescence: Findings from the first two waves of the 4-H Study of PYD.

King, P. E., Dowling, E. M., Mueller, R. A., White, K., Schultz, W., Osborn, P., Dickerson, E., Bobek, D. L., Lerner, R. M., Benson, P. L., \& Scales, P. C. (2005). Thriving in adolescence: The voices of youth-serving practitioners, parents, and early and late adolescents. Journal of Early Adolescence, 25(1), 94-112. 
Lerner, R. M. (2004). Liberty: Thriving and civic engagement among America's youth. Thousand Oaks, CA: Sage Publications.

Lerner, R. M., Dowling, E. M., \& Anderson, P. M. (2003). Positive youth development: Thriving as a basis of personhood and civil society. Applied Developmental Science, 7(3), 172-180.

Lerner, R., M., Lerner, J. V., Almerigi, J., Theokas, C., Phelps, E., Gestsdottir, S., Naudeau, S., Jelicic, H., Alberts, A., Ma, L., Smith, L., Bobek, D. L., Richman-Raphael, D., Simpson, I., Christiansen, E. D., \& von Eye, A. (2005). Positive youth development, participation in community youth development programs, and community contributions of fifth grade adolescents: Findings from the first wave of the 4-H Study of Positive Youth Development. Journal of Early Adolescence, 25, 17-71.

Roth, J. L., \& Brooks-Gunn, J. (2003a). What exactly is a youth development program? Answers from research and practice. Applied Developmental Science, 7(2), 94-111.

Roth, J. L., \& Brooks-Gunn, J. (2003b). Youth development programs: Risk, prevention and policy. Journal of Adolescent Health, 32(3), 170-182.

Scales, P. C., Benson, P. L., Leffert, N., \& Blyth, D. A. (2000). Contribution of developmental assets to the prediction of thriving among adolescents. Applied Developmental Science, 4(1), 27-46.

Strauss, A. \& Corbin, J. (1998). Basics of qualitative research: Techniques and procedures fordeveloping grounded theory. Thousand Oaks, CA: Sage Publications.

Theokas, C., Almerigi, J. B., Lerner, R. M., Dowling, E. M., Benson, P. L., Scales, P. C., \& von Eye, A. (2005). Conceptualizing and modeling individual and ecological asset components of thriving in early adolescence. Journal of Early Adolescence, 25(1), 113-143.

Theokas, C. \& Lerner, R. M. (In press). Observed ecological assets in families, schools, and neighborhoods: Conceptualization, measurement and relations with positive and negative developmental outcomes. Applied Developmental Science, 10(2).

This research was supported in part by a grant from the National 4-H Council. Reprint requests may be sent to Amy Alberts, Institute for Applied Research in Youth Development, 301 LincolnFilene Building, Tufts University, Medford, MA 02155 or to amy.alberts@tufts.edu

(C) Copyright of Journal of Youth Development Bridging Research and Practice. Content may not be copied or emailed to multiple sites or posted to a listserv without copyright holder's express written permission. Contact Editor at: patricia.dawson@oregonstate.edu for details. However, users may print, download or email articles for individual use.

ISSN 2325-4009 (Print); ISSN 2325-4017 (Online) 